\title{
The Relationship between Phytoplankton Evenness and Copepod Abundance in Lake Nansihu, China
}

\author{
Wang Tian, Huayong Zhang *, Lei Zhao, Xiang Xu and Hai Huang \\ Research Center for Engineering Ecology and Nonlinear Science, North China Electric Power University, \\ Beijing 102206, China; tianwang870822@163.com (W.T.); zhaolei@ncepu.edu.cn (L.Z.); \\ xuxiang229@163.com (X.X.); bjecology@gmail.com (H.H.) \\ * Correspondence: rceens@ncepu.edu.cn; Tel.: +86-10-61773936
}

Academic Editor: Miklas Scholz

Received: 12 May 2016; Accepted: 22 August 2016; Published: 31 August 2016

\begin{abstract}
The relationship between biodiversity and ecosystem functioning is a central issue in ecology. Previous studies have shown that producer diversity can impact the consumer community via predator-prey interactions. However, direct observations of this relationship remain rare, in particular for aquatic ecosystems. In this research, the relationship between phytoplankton diversity (species richness and evenness) and the abundance of copepods was analyzed in Lake Nansihu, a meso-eutrophic lake in China. The results showed that copepods abundance was significantly decreased with increasing phytoplankton evenness throughout the year. However, both species richness and phytoplankton biomass showed no significant relationship with the abundance of copepods. Canonical correspondence analysis revealed that phytoplankton evenness was negatively correlated with Thermocyclops kawamurai, Cyclops vicinus, Eucyclops serrulatus, Mesocyclops leuckarti, Sinocalanus tenellus, Sinocalanus dorrii, Copepods nauplius, but positively correlated with many Cyanophyta species (Chroococcus minutus, Dactylococcopsis acicularis, Microcystis incerta, Merismopedia tenuissima, Merismopedia sinica and Lyngbya limnetica). Based on our results, phytoplankton evenness was a better predictor of copepods abundance in meso-eutrophic lakes. These results provide new insights into the relationship between diversity and ecosystem functioning in aquatic ecosystems.
\end{abstract}

Keywords: phytoplankton biomass; species richness; evenness; copepod abundance; ecosystem functioning

\section{Introduction}

The Earth ecosystem is experiencing an unprecedented rate of biodiversity loss as a result of global climate change, eutrophication, and overexploitation of natural resources [1-3]. Lake ecosystems are relatively vulnerable and the loss of biodiversity may cause catastrophic consequences, such as algae blooms $[4,5]$. Phytoplankton, the most important primary producer in lakes, is particularly sensitive to variations in environmental factors [5-7]. Understanding the effects of phytoplankton diversity on ecosystem functioning is essential to developing appropriate conservation strategies in aquatic ecosystems $[5,8]$.

Aquatic ecosystems are special because their primary organisms (i.e., phytoplankton and zooplankton) are characterized by short generation times and efficient trophic transfer [9]. Phytoplankton diversity not only impacts the productivity, stability, resource use efficiency (measured as the amount of phytoplankton biomass produced per unit of phosphorus), and community turnover in its own trophic level [8,10-12], but also influences zooplankton through predator-prey interaction $[13,14]$. Ecologists have found that phytoplankton species richness could promote zooplankton abundance, a process known as "trophic overyielding" [14]. Filstrup et al. [12] showed 
that higher phytoplankton diversity (evenness) results in increased zooplankton resource use efficiency (measured as the amount of zooplankton biomass produced per unit of phytoplankton). It is commonly believed that communities with greater numbers of coexisting species are more resistant to predation [13]. The increase of producer species richness reduces the predation pressure and leads to smaller predator communities $[15,16]$. In addition, the relationship between biodiversity and ecosystem functioning varies with different metrics of diversity. For example, Ptacnik et al. [11] and Filstrup et al. [12] found contrary effects of phytoplankton species richness and evenness on community turnover rates. Therefore, the relationship between producer diversity and predator community is complex and has not reached a consistent conclusion, especially in natural aquatic ecosystems $[8,13,14]$.

Predator-prey interaction between phytoplankton and zooplankton is an important mechanism in aquatic ecosystems $[17,18]$. The strength of the interaction is related to the trophic state of the lake: in oligotrophic lakes, zooplankton is mainly composed of small-sized individuals $[19,20]$; in mesotrophic lakes, zooplankton is dominated by efficient grazer copepods $[19,20]$; and in eutrophic lakes, phytoplankton mostly consists of Cyanophyta, which is predation-resistant and not efficiently transferred to zooplankton community $[19,20]$. While both phytoplankton diversity and biomass influence the predator community, debate remains as to which is a better predictor of zooplankton.

The copepod community is relatively larger in body size and is much more efficient in predation as compared with other zooplankton communities [19-23]. Furthermore, phytoplankton and copepods were believed to exert a strong influence on each other, especially in mesotrophic lakes [24,25]. In this study, the relationship between phytoplankton (evenness, species richness and biomass) and the abundance of copepods was analyzed using data from Lake Nansihu, which is a typical lake in North China containing a significant abundance of both phytoplankton and copepods. The purpose of this work was to explore the effects of phytoplankton diversity on the abundance of copepods in aquatic ecosystems.

\section{Materials and Methods}

\subsection{Study Area}

Lake Nansihu $\left(116^{\circ} 34^{\prime} \mathrm{E}-117^{\circ} 21^{\prime} \mathrm{E}, 34^{\circ} 27^{\prime} \mathrm{N}-35^{\circ} 20^{\prime} \mathrm{N}\right)$, located in the northern of the Huai River Basin, is the largest freshwater lake in North China (Figure 1). The lake actually comprises four connected lakes: Nanyang, Dushan, Zhaoyang and Weishan. The total water area is $1266 \mathrm{~km}^{2}$ and the total capacity is $6.37 \times 10^{9} \mathrm{~m}^{3}$. The average water depth of the lake is $1.5 \mathrm{~m}$ and it is categorized as a shallow, open and plain grassland lake. The lake experiences a warm temperate monsoon climate with an annual average temperature of $13.7^{\circ} \mathrm{C}$. Annual rainfall varies from $550 \mathrm{~mm}$ to $720 \mathrm{~mm}$, with nearly $60 \%$ of precipitation occurring during the summer rainy season.

In the early 1980s, the lake was in a healthy state and contained 116 phytoplankton genera and 249 zooplankton species [26-28]. Since the late 1980s, pollution from external untreated industrial wastewater and agricultural runoff increased [27]. In 2000, the mean concentrations of total nitrogen (TN) and total phosphorus (TP) were $3.7 \mathrm{mg} / \mathrm{L}$ and $0.15 \mathrm{mg} / \mathrm{L}$, respectively [26]. Plankton diversity decreased to the lowest level with only 36 phytoplankton species and 28 zooplankton species in 2002 [28]. Lake Nansihu was selected as a water delivery channel and storage lake for the great South-to-North Water Diversion Project in 2002. Then many ecological restoration projects were implemented to improve water quality. Mean concentrations of TN and TP had decreased to $1.01 \mathrm{mg} / \mathrm{L}$ and $0.09 \mathrm{mg} / \mathrm{L}$ in 2010 [29]. A total of 86 phytoplankton species and 52 zooplankton species were identified in 2007, which was much larger than that in 2002 [28]. There were six copepod species in the lake and their mean abundance was 70 ind./L in 2010 [30]. Lake Nansihu is currently in a meso-eutrophic state and the main health risk is algae blooms [31]. 


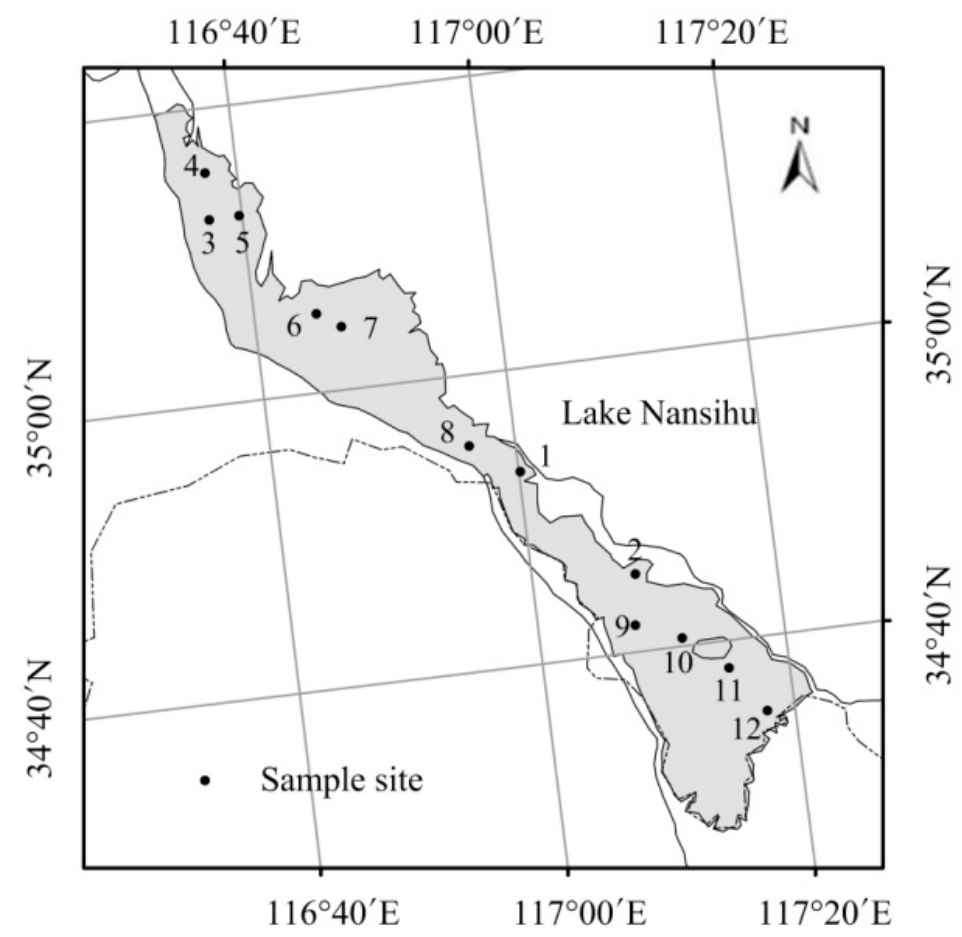

Figure 1. Location of Lake Nansihu and sampling sites in the lake. The figure was made by ArcGIS version 10.0 (ESRI, Redlands, CA, USA).

\subsection{Sampling and Measurements}

Data were collected from 12 sampling sites evenly distributed throughout the lake (Figure 1). Field investigations were conducted in early April, July, September, and late November from 2011 to 2014. Measurements and samplings were carried out between 8:00 A.M. and 10:00 A.M. along the same route.

For phytoplankton samples, equivalent amount of water was collected at depth of $0.5 \mathrm{~m}$ and $1.0 \mathrm{~m}$ using a water sampler, and then $1 \mathrm{~L}$ of the well-mixed water was taken. The samples were preserved with acidified Lugol's solution for $24 \mathrm{~h}$ and condensed to $30 \mathrm{~mL}$. Finally, a $0.1 \mathrm{~mL}-$ aliquot of the condensed sample was added to a phytoplankton counting box to allow for the identification and quantification of species [32]. The biomass of each phytoplankton species was calculated by cell volume [33]. Phytoplankton species richness was calculated as the number of species identified for each sample site.

For copepod samples, an equivalent amount of water was collected at depth of $0.5 \mathrm{~m}$ and $1.0 \mathrm{~m}$ using a water sampler, and then $1 \mathrm{~L}$ of the well-mixed water was taken. The samples were preserved with formaldehyde (4\%) for $24 \mathrm{~h}$. Then the samples were condensed to $50 \mathrm{~mL}$ and $1 \mathrm{~mL}$ of the condensed sample was used to identify and count the individuals of each copepod species under a microscope. Copepod abundance was expressed as the number of individuals per liter (ind./L).

Environmental factors were investigated at the same time with plankton in the four seasons of 2013. Water temperature (WT), dissolved oxygen (DO), and $\mathrm{pH}$ were measured in situ using YSI Professional Plus (YSI Incorporated, Yellow Springs, OH, USA) at each of the 12 sites. Water transparency (SD) was measured with a Secchi disk. Water quality samples were collected using a Tygon tube water sampler at $0.30 \mathrm{~m}$ under the water surface. Samples were stored in acid-cleaned glass bottles at $4{ }^{\circ} \mathrm{C}$ and filtered through a $0.45-\mu \mathrm{m}$ acetate filter for subsequent analysis. The concentration of TN was measured via potassium persulfate oxidation-UV spectrophotometry, and TP was determined by Mo-Sb Anti-spectrophotometry method. 


\subsection{Calculation of Evenness and Statistical Analysis}

Phytoplankton evenness was expressed using Pielou's Evenness Index [34]:

$$
\begin{gathered}
H=-\sum_{i=1}^{S} P_{i} \ln P_{i} \\
P_{i}=N_{i} / N \\
J=H / \ln S
\end{gathered}
$$

where $P_{i}$ is the biomass proportion of phytoplankton species $i$ in the sample, $S$ is the species richness, and $J$ is Pielou's Evenness Index.

The differences of environmental factors in different seasons and sites were analyzed via one-way ANOVA. Prior to analysis, the Kolmogorov-Smirnov method was used to test whether data were normally distributed, and the Bartlett test was performed to assess the homogeneity of variance. Post-hoc comparisons were applied using the Turkey HSD test at a significance level of 0.05 (function "glht" within the "multcomp" package). The correlation coefficients among copepods abundance, phytoplankton species richness, evenness and biomass were calculated by linear Pearson correlation.

Considering that the 12 sites had different environmental factors and phytoplankton conditions, we separately analyzed the relationships between phytoplankton (evenness, species richness and biomass) and copepods abundance using a Linear Mixed Effects Model with a maximum-likelihood estimator (function "lme" with "method = ML" within the "nlme" package in $R$ 3.2.3). The 12 sites were included in the model as a random factor to correct for differences between sites.

Principal components analysis (PCA) was used to test the similarity of plankton community composition at different sites and whether there were apparent spatial characteristics. Mean values of phytoplankton and copepods species abundance at each site during the research time were used as the species matrix. The relationships among plankton species composition and environmental variables were analyzed using canonical correspondence analysis (CCA). The environmental matrix for CCA was including the values of $\mathrm{WT}, \mathrm{DO}, \mathrm{pH}, \mathrm{SD}, \mathrm{TN}, \mathrm{TP}$, phytoplankton biomass, species richness and evenness in the four seasons of 2013. Species matrix for CCA used the plankton data in the four seasons of 2013. Plankton species were selected for CCA through the following standards: the species appeared in at least $30 \%$ of the samples and contributed to $\geq 1 \%$ of total plankton abundance in at least one sample. All the variables were transformed by $\log _{10}(x+1)$ except for $\mathrm{pH}$. Both PCA and CCA were conducted using Canoco for Windows 4.5 (Biometris, Wageningen, The Netherlands), and the figures were drawn using Canodraw for Windows (Biometris, Wageningen, The Netherlands).

\section{Results}

\subsection{Variations of the Environmental Factors}

Mean WT at the 12 sites ranged from $21.4{ }^{\circ} \mathrm{C}$ to $22.2{ }^{\circ} \mathrm{C}$ and there were no significant differences among these sites $\left(F_{(11,36)}=0.04, p=0.95\right)$. Mean WT varied seasonally $\left(F_{(3,44)}=441.9, p<0.001\right)$ and had a significantly higher value in summer than in spring $(p<0.001)$, autumn $(p<0.001)$, and winter $(p<0.001)$. The DO concentration in the lake was relatively high and there were significant differences among the 12 sites $\left(F_{(11,36)}=1.85, p<0.05\right)$, with mean value at Site 9 significantly lower than that at Site $3(p=0.007)$ and Site $7(p=0.022)$. Mean DO concentrations in the lake were similar during the spring, summer, and autumn $\left(F_{(2,33)}=0.530, p=0.594\right)$. However, in winter the mean concentration of DO was significantly higher than that in autumn $(p<0.05)$. Most of the sites in the lake showed weak alkaline with a variation of $\mathrm{pH}$ from 7.48 to 7.94 (Table 1). Values of $\mathrm{pH}$ showed significant seasonal variation $\left(F_{(3,44)}=6.67, p=0.001\right)$, with summer $\mathrm{pH}$ significantly higher than that in spring $(p=0.032)$ and winter $(p<0.001)$. The lake had a low SD, with mean values lower than $1 \mathrm{~m}$ at all 12 sites (Table 1$)$, and there were no significant seasonal variations in mean transparent values $\left(F_{(3,44)}=1.96, p=0.135\right)$. 
The nutrient concentrations in the lake were enriched, as shown in Table 1. The mean concentration of $\mathrm{TN}$ ranged between $0.72 \mathrm{mg} / \mathrm{L}$ and $1.59 \mathrm{mg} / \mathrm{L}$ at different sites, and there were significant differences among the 12 sites for $\mathrm{TN}\left(F_{(11,36)}=2.37, p<0.05\right)$. The TN concentration at Site 2 was significantly higher than that at Site $3(p=0.021)$ and Site $6(p=0.007)$. Besides, the TN concentration in the summer was significantly higher than that in spring $(p=0.024)$. There were no significant differences among all sites for $\operatorname{TP}\left(F_{(11,36)}=0.64, p=0.28\right)$. However, there were significant seasonal variations among TP concentrations $\left(F_{(3,44)}=15.5, p<0.001\right)$, with the mean TP concentration in summer significantly higher than that in the winter $(p<0.001)$.

Table 1. Environmental factors for each sample site, values are expressed as mean \pm standard deviation. WT: water temperature; DO: dissolved oxygen; SD: Water transparency; TN: total nitrogen; TP: total phosphorus.

\begin{tabular}{ccccccc}
\hline Sites & $\mathbf{W T}\left({ }^{\circ} \mathbf{C}\right)$ & $\mathbf{D O}(\mathbf{m g} / \mathbf{L})$ & $\mathbf{p H}$ & $\mathbf{S D}(\mathbf{c m})$ & $\mathbf{T N}(\mathbf{m g} / \mathbf{L})$ & $\mathbf{T P}(\mathbf{m g} / \mathbf{L})$ \\
\hline 1 & $22.14 \pm 10.03$ & $10.47 \pm 2.94$ & $7.83 \pm 0.69$ & $40.75 \pm 9.22$ & $1.19 \pm 0.31$ & $0.24 \pm 0.11$ \\
2 & $21.94 \pm 10.03$ & $8.22 \pm 1.90$ & $7.69 \pm 0.25$ & $58.00 \pm 5.89$ & $1.22 \pm 0.21$ & $0.09 \pm 0.04$ \\
3 & $21.38 \pm 9.96$ & $9.27 \pm 0.36$ & $7.55 \pm 0.66$ & $40.25 \pm 7.68$ & $0.80 \pm 0.18$ & $0.12 \pm 0.09$ \\
4 & $22.15 \pm 9.58$ & $9.13 \pm 1.23$ & $7.91 \pm 0.46$ & $87.88 \pm 10.82$ & $1.17 \pm 0.15$ & $0.11 \pm 0.06$ \\
5 & $21.59 \pm 9.27$ & $8.43 \pm 1.19$ & $7.88 \pm 0.51$ & $65.38 \pm 9.33$ & $1.18 \pm 0.24$ & $0.10 \pm 0.06$ \\
6 & $21.93 \pm 10.24$ & $9.49 \pm 1.34$ & $7.69 \pm 0.75$ & $89.87 \pm 11.91$ & $0.72 \pm 0.15$ & $0.11 \pm 0.09$ \\
7 & $21.61 \pm 11.01$ & $9.59 \pm 1.41$ & $7.88 \pm 0.62$ & $49.00 \pm 8.25$ & $1.03 \pm 0.25$ & $0.17 \pm 0.10$ \\
8 & $21.61 \pm 9.48$ & $7.31 \pm 1.05$ & $7.70 \pm 0.37$ & $48.02 \pm 10.31$ & $1.59 \pm 0.34$ & $0.24 \pm 0.11$ \\
9 & $22.73 \pm 6.50$ & $6.74 \pm 1.21$ & $7.51 \pm 0.36$ & $72.63 \pm 12.42$ & $1.30 \pm 0.28$ & $0.13 \pm 0.06$ \\
10 & $21.16 \pm 9.95$ & $7.63 \pm 1.83$ & $7.48 \pm 0.34$ & $38.00 \pm 8.36$ & $1.27 \pm 0.37$ & $0.14 \pm 0.10$ \\
11 & $21.21 \pm 9.72$ & $9.11 \pm 1.89$ & $7.61 \pm 0.47$ & $46.62 \pm 4.23$ & $1.36 \pm 0.24$ & $0.11 \pm 0.09$ \\
12 & $21.47 \pm 9.79$ & $11.01 \pm 1.69$ & $7.94 \pm 0.53$ & $74.87 \pm 9.55$ & $1.16 \pm 0.31$ & $0.18 \pm 0.11$ \\
\hline
\end{tabular}

\subsection{Seasonal and Spatial Variations of Phytoplankton Community}

In total, 138 phytoplankton species belonging to 78 genera and eight phyla were identified between 2011 and 2014. The phytoplankton community included 60 Chlorophyta species, 33 Bacillariophyta species, 20 Cyanophyta species, and 14 Euglenophyta species. Species belonging to other communities were relatively rare.

The mean values of phytoplankton species richness varied seasonally from 37.5 (winter 2012) to 55.8 (summer 2013), with annual maximum values in summer and minimum values in winter (Figure 2a). In different sample sites, phytoplankton species richness ranged between 22 and 88 with large seasonal standard deviations (varied between 7.29 and 12.96; Figure 2a). Phytoplankton evenness was high with mean values ranging between 0.74 (spring 2014) and 0.87 (summer 2013; Figure $2 b$ ). Variation in phytoplankton evenness was irregular and sometimes significant between adjacent seasons (e.g., in 2012 mean phytoplankton evenness ranged from 0.85 in summer to 0.75 in autumn; Figure 2b).

Mean phytoplankton biomass across the study was $2.19 \mathrm{mg} / \mathrm{L}$; however, there were significant seasonal variations (Figure 2c), with mean phytoplankton biomass varying between $0.44 \mathrm{mg} / \mathrm{L}$ (winter 2013) and $5.46 \mathrm{mg} / \mathrm{L}$ (summer 2011). Chlorophyta was the dominant community in the lake with a mean biomass of $0.94 \mathrm{mg} / \mathrm{L}$, which accounted for $43.0 \%$ of the total phytoplankton biomass. The mean biomasses of Bacillariophyta and Euglenophyta were almost equal $(0.45 \mathrm{mg} / \mathrm{L}$ and $0.43 \mathrm{mg} / \mathrm{L}$ respectively). Cyanophyta had a relatively lower mean biomass $(0.20 \mathrm{mg} / \mathrm{L})$ and its proportion was $8.92 \%$. Phytoplankton biomasses were notably lower at Sites 6 and 10 than they were at other sites (Figure 3a). Site 8 had the highest proportion of Cyanophyta biomass, and its value reached $12.7 \%$. The biomasses of Chlorophyta at Sites 8 and 9 were higher than that at other sites (Figure 3a). Site 4 had the highest value of Euglenophyta biomass. 

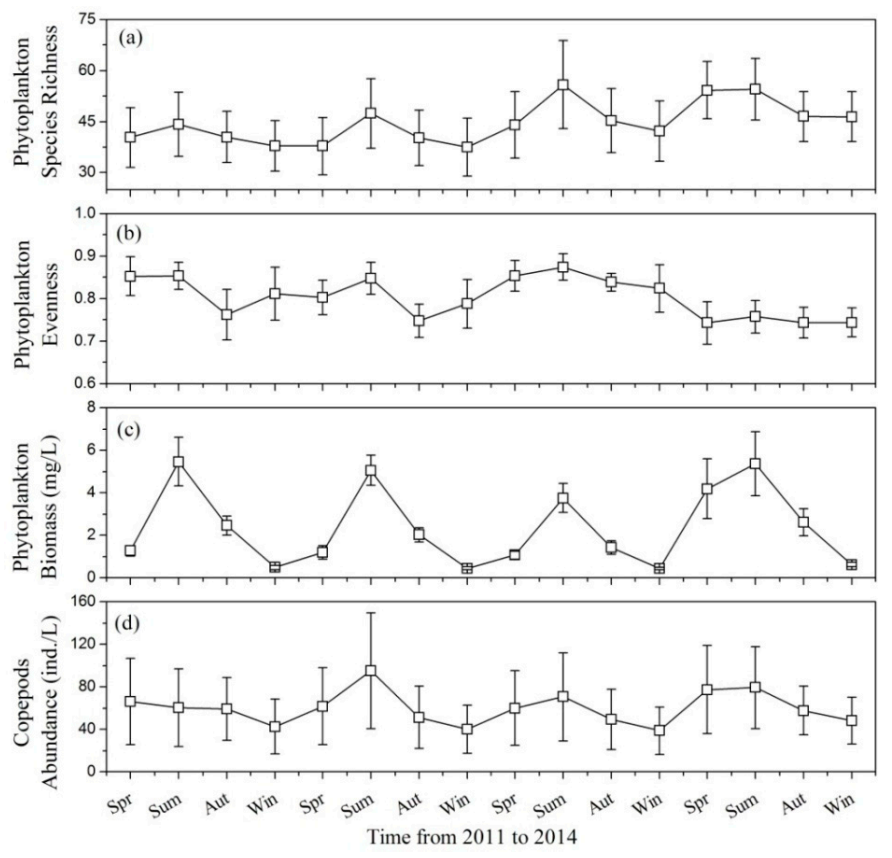

Figure 2. Seasonal variations in (a) phytoplankton species richness; (b) phytoplankton evenness; (c) phytoplankton biomass; and (d) copepods abundance. Values are expressed as mean \pm standard deviation of the 12 sample sites. Spr: spring, Sum: summer, Aut: autumn, Win: winter.

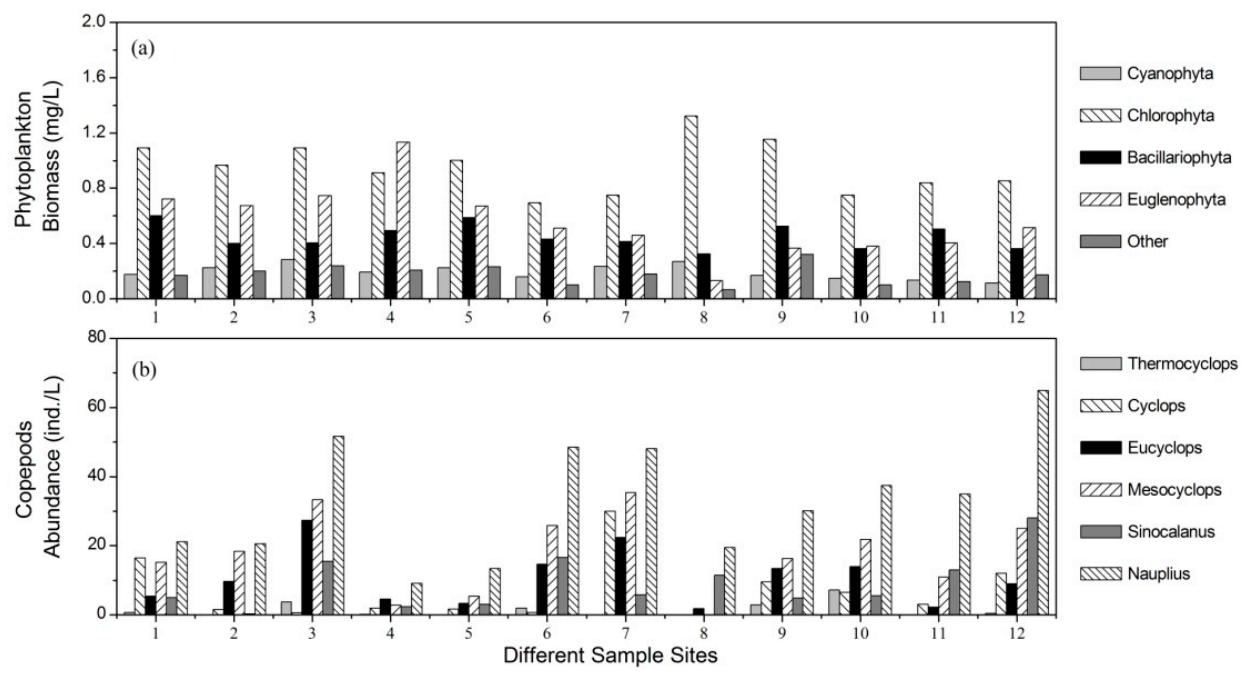

Figure 3. The community compositions of (a) phytoplankton and (b) copepods at different sites.

\subsection{Seasonal and Spatial Variations in Copepods Abundance}

In total, 12 copepod species were identified, including Thermocyclops hyalinus, Thermocyclops taihokuensis, Thermocyclops kawamurai, Cyclops vicinus, Tropocyclops prasinus jerseyensis, Eucyclops serrulatus, Mesocyclops leuckarti, Eucyclops speratus, Sinocalanus tenellus, Sinocalanus dorrii, Cletocamptus, and Copepods nauplius. The dominant species were C. vicinus, M. leuckarti, S. dorrii, and Copepods nauplius.

Mean copepod abundance ranged from 38.6 ind./L (winter 2013) to 95.1 ind./L (summer 2012) in different seasons (Figure 2d), and was relatively higher in spring and summer than in autumn and winter (Figure 2d). Copepod abundance also varied significantly between different sample sites, as shown by the large standard deviation values (Figure 2d). Mean copepod abundance at Sites 3, 7 and 12 were much higher than those at the other sites (Figure 3b). The mean biomasses of Cyclops and 
Mesocyclops reached their maximum values at Site 7 (Figure 3b); however, the maximum values for Eucyclops and Sinocalanus were observed at Sites 3 and 12, respectively.

The results of the PCA for the first two components are presented in the biplot (Figure 4). The eigenvalues of the first two axes were 0.395 and 0.275 , respectively, and the contribution of the first two principal components to the percentage of variance was $67.1 \%$. The first principal component was primarily driven by both phytoplankton and copepods species, while the second principal component was primarily driven by Cyclotella, Synedra, Lyngbya, Closterium, Scenedesmus genera and some other Chllorophyta species. Sites 3 and 7 were similar in plankton composition and were distributed in the positive direction of the first principal component (Figure 4). Sites 4 and 5 were distributed within the second quadrant, and both had low copepods abundance and similar phytoplankton compositions (Figure 3). Site 8 was located within the third quadrant and the remaining sites were mainly distributed near the origin of the coordinates (Figure 4). Thus, there were apparent differences for plankton community composition among the 12 sites. However, plankton community composition did not show apparent latitudinal distribution.

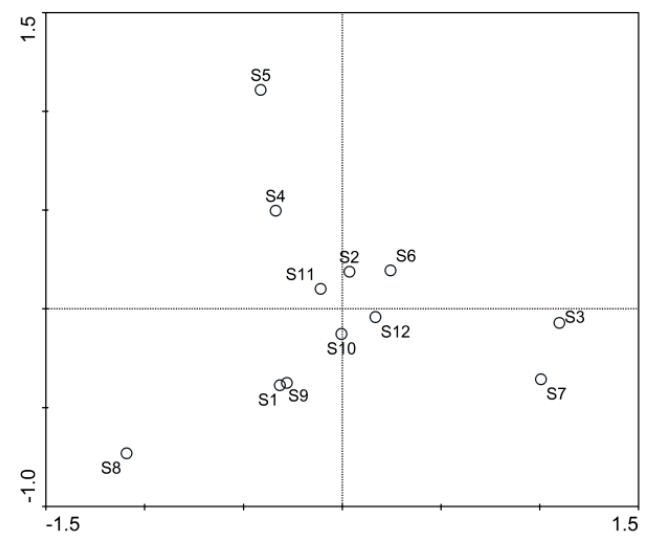

Figure 4. PCA biplot of spatial distribution characters for plankton community in Lake Nansihu. S1 to S12 were standing for the 12 sample sites in the lake.

\subsection{Relationship between Phytoplankton Evenness and Copepods Abundance}

Phytoplankton evenness was negatively correlated with copepod abundance in all four seasons (spring, $R=-0.532, p<0.001$; summer, $R=-0.355, p<0.05$; autumn, $R=-0.372, p<0.05$; winter, $R=-0.616, p<0.001)$. A Linear Mixed Effects Model showed that phytoplankton evenness was significantly correlated with the abundance of copepods throughout the year (Table 2; Figure 5), with regression slopes of $-76.57(t=-3.78, p<0.001),-46.83(t=-2.53, p=0.021),-83.03(t=-2.97$, $p=0.005)$, and $-44.16(t=-2.39, p=0.023)$, respectively.

Table 2. Linear Mixed Effects Model analyses for the relationship between phytoplankton evenness and copepod abundance in different seasons.

\begin{tabular}{ccccccc}
\hline Seasons & Variables & Value & Standard Error & Degree of Freedom & $\boldsymbol{t}$-Value & $p$-Value \\
\hline \multirow{2}{*}{ Spring } & Intercept & 127.3 & 19.43 & 35 & 6.55 & $<0.001$ \\
& Slope & -76.57 & 20.28 & 35 & -3.78 & $<0.001$ \\
\hline \multirow{2}{*}{ Summer } & Intercept & 114.82 & 49.67 & 35 & 2.31 & 0.027 \\
& Slope & -46.83 & 18.50 & 35 & -2.53 & 0.021 \\
\hline \multirow{2}{*}{ Autumn } & Intercept & 117.83 & 22.86 & 35 & 5.15 & $<0.001$ \\
& Slope & -83.03 & 27.92 & 35 & -2.97 & 0.005 \\
\hline \multirow{2}{*}{ Winter } & Intercept & 76.58 & 15.90 & 35 & 4.82 & $<0.001$ \\
& Slope & -44.16 & 18.45 & 35 & -2.39 & 0.023 \\
\hline
\end{tabular}




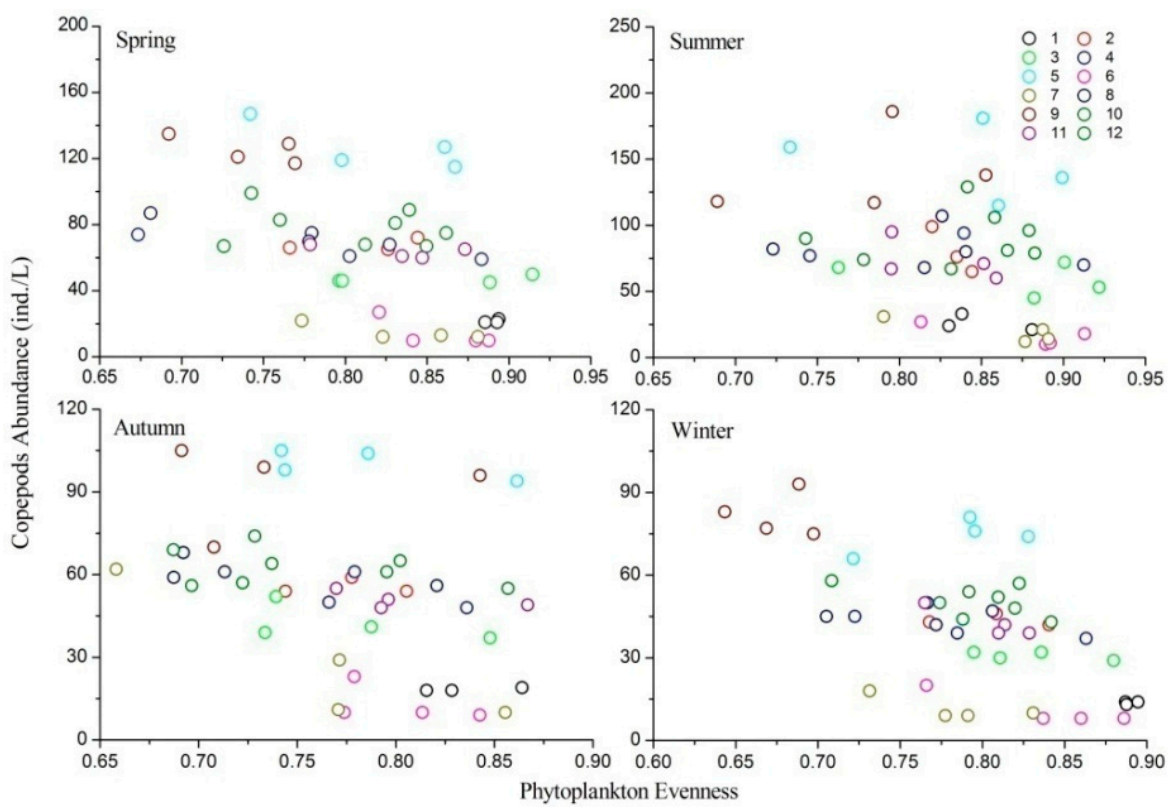

Figure 5. Relationships between phytoplankton evenness and copepod abundance in different seasons.

\subsection{Relationship between Phytoplankton Species Richness and Copepod Abundance}

Linear Pearson correlation coefficients between phytoplankton species richness and copepod abundance in the four seasons were $R=0.236, R=0.114, R=0.213$ and $R=0.262$, respectively, which were all found to be insignificant $(p>0.05)$. The Linear Mixed Effects Model also showed that phytoplankton species richness had no significant correlation with the abundance of copepods (Table 3; Figure 6). The regression slopes in the four seasons were $0.468(t=1.410, p=0.172), 0.027(t=0.066$, $p=0.947), 0.002(t=0.001, p=0.990)$ and $0.205(t=1.414, p=0.167)$, respectively. All these regressions slopes were positive but not significant $(p>0.05)$.

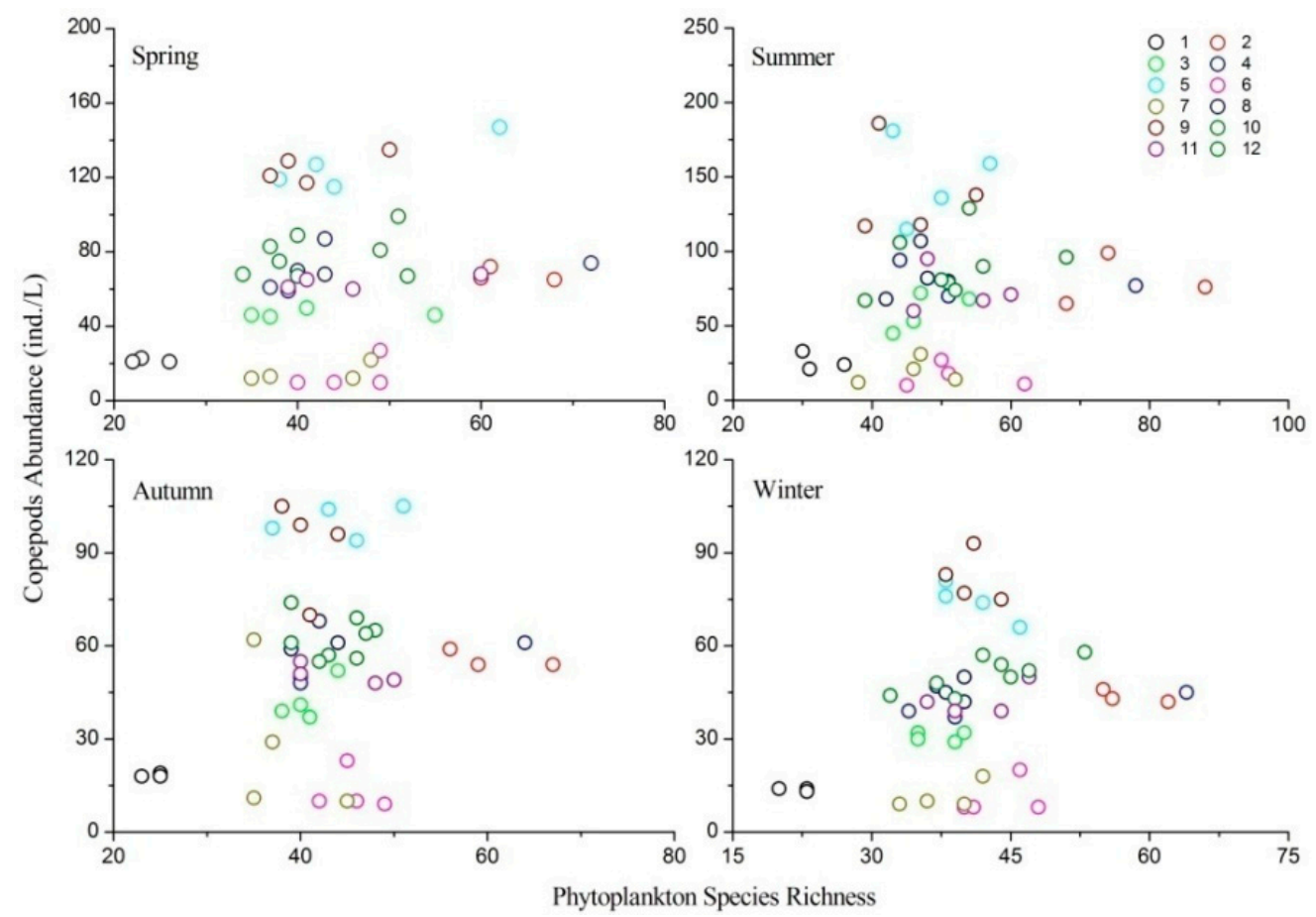

Figure 6. Relationships between phytoplankton species richness and copepod abundance in different seasons. 
Table 3. Linear Mixed Effects Model analyses for the relationship between phytoplankton species richness and copepod abundance in different seasons.

\begin{tabular}{ccccccc}
\hline \multirow{2}{*}{ Seasons } & Variables & Value & $\begin{array}{c}\text { Standard } \\
\text { Error }\end{array}$ & $\begin{array}{c}\text { Degree of } \\
\text { Freedom }\end{array}$ & $t$-Value & $p$-Value \\
\hline \multirow{2}{*}{ Spring } & Intercept & 44.34 & 12.05 & 35 & 3.681 & $<0.001$ \\
& Slope & 0.468 & 0.332 & 35 & 1.410 & 0.172 \\
\hline \multirow{2}{*}{ Summer } & Intercept & 74.32 & 23.68 & 35 & 3.138 & 0.003 \\
& Slope & 0.027 & 0.400 & 35 & 0.066 & 0.947 \\
\hline \multirow{2}{*}{ Autumn } & Intercept & 53.35 & 15.67 & 35 & 3.404 & 0.002 \\
& Slope & 0.002 & 0.317 & 35 & 0.001 & 0.990 \\
\hline \multirow{2}{*}{ Winter } & Intercept & 33.07 & 8.739 & 35 & 3.784 & $<0.001$ \\
& Slope & 0.205 & 0.145 & 35 & 1.414 & 0.167 \\
\hline
\end{tabular}

\subsection{Relationship between Phytoplankton Biomass and Copepods Abundance}

Pearson correlation coefficients between phytoplankton biomass and copepod abundance for the four seasons were $R=0.030, R=-0.146, R=-0.027$, and $R=-0.128$, respectively, which were all insignificant $(p>0.05)$. However, the Linear Mixed Effects Model showed that the relationship between phytoplankton biomass and copepod abundance varied seasonally (Table 4; Figure 7). In spring, phytoplankton biomass had a positive correlation with copepod abundance and the regression slope was $3.597(t=6.715, p<0.001)$. However, the regression slopes in summer, autumn, and winter were all positive, none were significant (Table 4). The correlation coefficients between phytoplankton evenness and biomass for the four seasons (spring, summer, autumn, and winter) were $R=-0.153$, $R=-0.103, R=-0.211$, and $R=-0.171$, respectively. In addition, the correlation coefficients between phytoplankton species richness and biomass were always insignificant (spring: $R=0.213$; summer: $R=0.106$; autumn: $R=0.057$; winter, $R=0.206$ ). These results showed that phytoplankton evenness and species richness had no significant correlation with biomass.

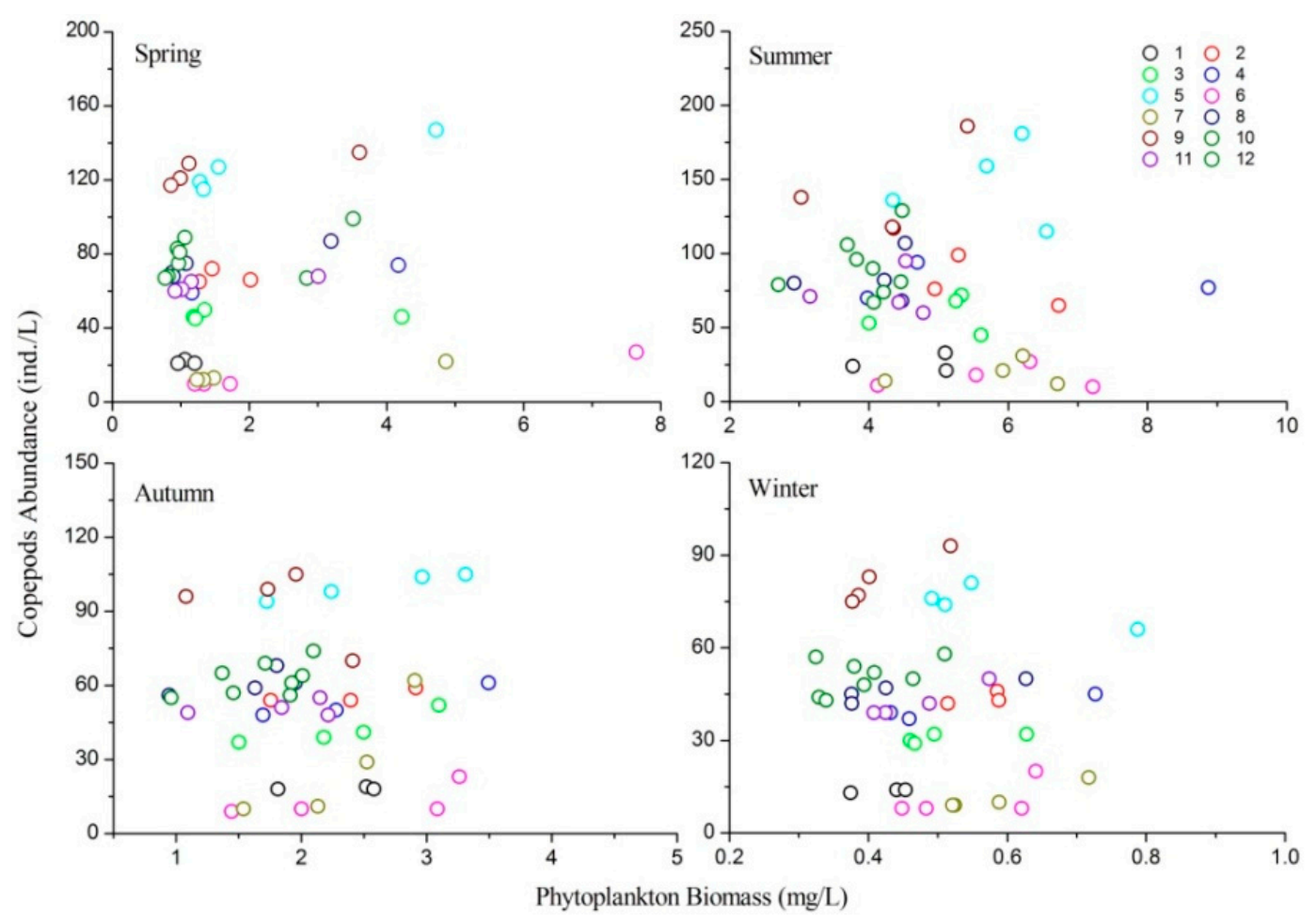

Figure 7. Relationships between phytoplankton biomass and copepod abundance in different seasons. 
Table 4. Linear Mixed Effects Model analyses for the relationship between phytoplankton biomass and copepod abundance in different seasons.

\begin{tabular}{ccccccc}
\hline Seasons & Variables & Value & Standard Error & Degree of Freedom & $\boldsymbol{t}$-Value & $p$-Value \\
\hline \multirow{2}{*}{ Spring } & Intercept & 58.28 & 11.00 & 35 & 5.298 & $<0.001$ \\
& Slope & 3.597 & 0.536 & 35 & 6.715 & $<0.001$ \\
\hline \multirow{2}{*}{ Summer } & Intercept & 71.05 & 19.01 & 35 & 3.738 & $<0.001$ \\
& Slope & 0.941 & 2.969 & 35 & 0.317 & 0.753 \\
\hline \multirow{2}{*}{ Autumn } & Intercept & 39.52 & 9.504 & 35 & 4.158 & $<0.001$ \\
& Slope & 6.564 & 3.551 & 35 & 1.848 & 0.085 \\
\hline \multirow{2}{*}{ Winter } & Intercept & 30.99 & 7.684 & 35 & 4.033 & $<0.001$ \\
& Slope & 11.29 & 7.714 & 35 & 1.463 & 0.161 \\
\hline
\end{tabular}

\subsection{Influence of Environmental Factors and Phytoplankton on Copepods Abundance}

Results of CCA showed that the first two environmental factors axes were all vertical, and the first two species axes were nearly perpendicular. The eigenvalues of the first two axes were 0.116 and 0.042 , respectively. These axes explained $62.1 \%$ of the total variance of the plankton species listed in Table 5 . The correlation coefficients between the first two environmental axes and species axis were 0.903 and 0.790 . Species axis 1 was positively correlated with phytoplankton biomass $(R=0.703)$, but had a weak negative relationship with species richness $(R=-0.210)$. Species axis 2 was negatively correlated with phytoplankton evenness $(R=-0.533), \mathrm{SD}(R=-0.476)$ and WT $(R=-0.406)$, but had a weak positive relationship with $\mathrm{DO}(R=0.173)$.

Table 5. Codes and Latin names of plankton species for CCA.

\begin{tabular}{llllll}
\hline Code & Latin Name & Code & Latin Name & Code & Latin Name \\
\hline P1 & Distigma acutum & P2 & Euglena lucens & P3 & Phacus helicoides \\
P4 & Euglena mutabilis & P5 & Euglena caudata & P6 & Cyclotella sp. \\
P7 & Melosira granulata & P8 & Nitzschia sublinearis & P9 & Synedra sp. \\
P10 & Navicula simplex & P11 & Fragilaria capucina & P12 & Monallantus brevicylindrus \\
P13 & Oscillatoria princeps & P14 & Oscillatoria tenuis & P15 & Chroococcus minutus \\
P16 & Chroococcus tenax & P17 & Dactylococcopsis acicularis & P18 & Microcystis incerta \\
P19 & Phormidium tenue & P20 & Merismopedia tenuissima & P21 & Merismopedia sinica \\
P22 & Lyngbya limnetica & P23 & Lyngbya major & P24 & Lyngbya contorta \\
P25 & Cylindrospermum stagnale & P26 & Closterium gracile & P27 & Chlorella sp. \\
P28 & Schroederia setigera & P29 & Scenedesmus quadricauda & P30 & Scenedesmus dimorphus \\
P31 & Crucigenia tetrapedia & P32 & Actinastrum sp. & Z1 & Thermocyclops hyalinus \\
Z2 & Thermocyclops taihokuensis & Z3 & Thermocyclops kawamurai & Z4 & Cyclops vicinus \\
Z5 & Tropocyclops prasinus jerseyensis & Z6 & Eucyclops serrulatus & Z7 & Mesocyclops leuckarti \\
Z8 & Eucyclops speratus & Z9 & Sinocalanus tenellus & Z10 & Sinocalanus dorrii \\
Z11 & Cletocamptus & Z12 & Copepods nauplius & & \\
\hline
\end{tabular}

Copepod species T. kawamurai (Z3), C. vicinus (Z4), E. Serrulatus (Z6), M. leuckarti (Z7), S. tenellus (Z9), S. dorrii (Z10), Copepods nauplius (Z12) were distributed in the positive direction of axis 2, and their abundance was negatively correlated with phytoplankton evenness. However, T. hyalinus (Z1), T. taihokuensis (Z2) and E. speratus (Z8) were distributed in the fourth quadrant, and their abundance was primarily influenced by phytoplankton biomass (Figure 8). The biomasses of Cyanophyta species C. minutus (P15), M. incerta (P18), M. tenuissima (P20), M. sinica (P21), and L. limnetica (P22) had a weak positive relationship with phytoplankton evenness. In addition, phytoplankton evenness had positive relationships with the biomasses of Euglenophyta species D. acutum (P1), P. helicoides (P3), Bacillariophyta species F. capucina (P11). Chlorophyta species C. gracile (P26), S. dimorphus (P30) and $C$. tetrapedia (P31) had a negative relationship with phytoplankton evenness. Phytoplankton species richness was positively correlated with Euglenophyta species E. lucens (P2) and E. mutabilis (P4), Cyanophyta species O. princeps (P13) and O. tenuis (P14). 


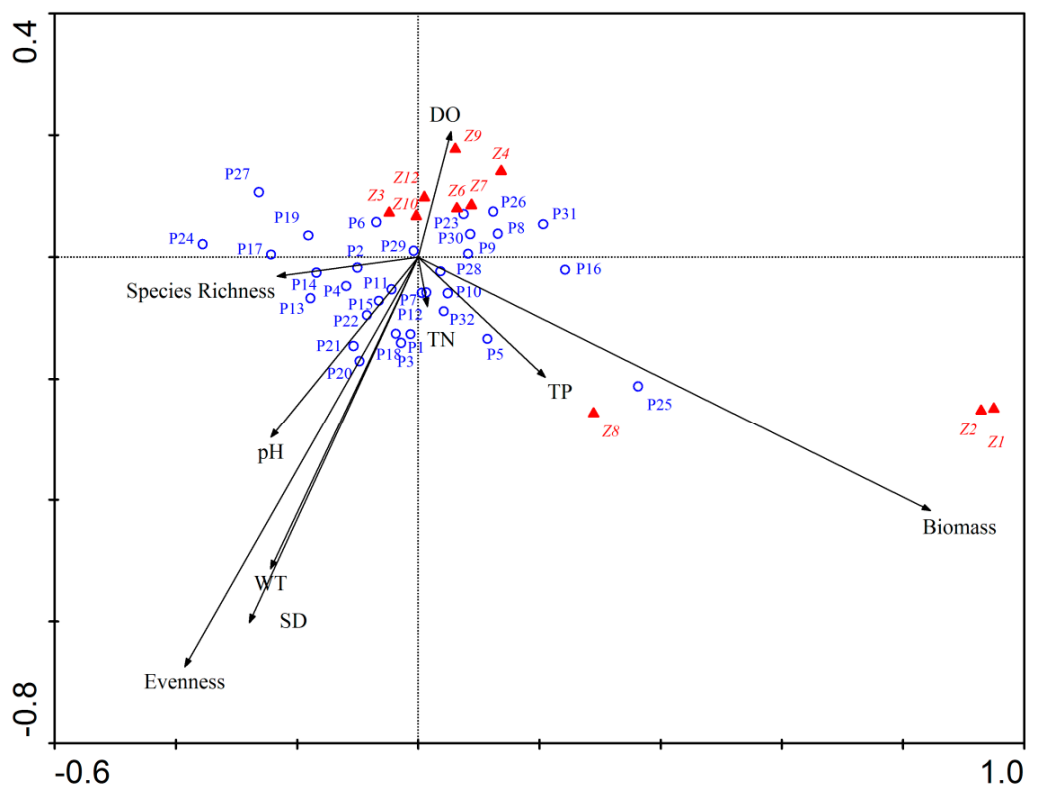

Figure 8. CCA biplot for the relationships among plankton species composition and environmental variables.

Concentration of DO had positive influence on most copepods species but had a negative relationship with many phytoplankton species as shown in Figure 8. Nutrient concentration in the lake had relatively weak influence on plankton community (Figure 8). However, TP had a strong correlation with the abundance of E. speratus (Z8) and phytoplankton biomass. SD, WT and pH were the main environmental factors that influence plankton community and they all positively correlated with phytoplankton evenness (Figure 8). The values of $\mathrm{pH}$ was strongly correlated with Cyanophyta species C. minutus (P15), M. tenuissima (P20), M. sinica (P21), and L. limnetica (P22). WT and SD had a strong positive relationship with Cyanophyta species $M$. incerta (P18), M. tenuissima (P20) and Euglenophyta species D. acutum (P1) and P. helicoides (P3).

\section{Discussion}

Phytoplankton diversity is thought to influence zooplankton through predator-prey interaction [13,14]. Based on a manipulated experiment, Striebel et al. [14] showed that phytoplankton communities with larger species richness could generate higher Daphnia growth rates and abundance under constant phytoplankton biomass. However, the results of this study found no significant relationship between phytoplankton species richness and copepod abundance in the natural aquatic ecosystem of Lake Nansihu (Figure 6; Table 3). Both phytoplankton species richness and evenness were insignificantly correlated with biomass. Phytoplankton species richness ranged from 1 to 10 in the experiment of Striebel et al. [14], while in this study, it varied between 22 and 88 . This discrepancy suggests that the "trophic overyielding" is only observed in the simple man-made community, and is not appeared in complex and highly evolutionary ecosystems. Therefore, the relationship between phytoplankton species richness and zooplankton abundance has not formed a consistent conclusion and further investigations are needed.

Filstrup et al. [12] found that higher phytoplankton evenness resulted in larger zooplankton resource use efficiency. However, the results of this study showed a negative relationship between phytoplankton evenness and copepod abundance. In the research of Filstrup et al. [12], plankton samples were collected from heavy eutrophic lakes and phytoplankton evenness ranged from 0 to 0.75. Phytoplankton community with low evenness was dominated by few Cyanophyta genera and the biomass proportion of Cyanophyta was higher than 75\% at most sites in their study [12]. Cyanophyta was predation-resistant and not efficiently transferred to zooplankton community $[12,19,20]$. Thus, phytoplankton evenness was positively related to zooplankton resource use efficiency [12]. 
Lake Nansihu was meso-eutrophic and phytoplankton evenness varied between 0.64 and 0.93 . The mean biomass of Cyanophyta was $0.20 \mathrm{mg} / \mathrm{L}$ and its proportion was $8.92 \%$, which were relatively lower than other phyla. WT, SD and $\mathrm{pH}$ were the main environmental factors that influence plankton community in the lake while the effects of nutrients were relatively weak (Figure 8). WT, SD and $\mathrm{pH}$ had a strong positive relationship with many Cyanophyta species (Figure 8). The increase of Cyanophyta biomass increased the uniformity of the phytoplankton community. As a result, there was a positive relationship between phytoplankton evenness and the biomass of many Cyanophyta species (Figure 8). Thus phytoplankton community with higher level of evenness comprised larger biomass of Cyanophyta species, which were more resistant to predation by copepods and lead to a negative relationship between phytoplankton evenness and copepods abundance. These results suggest that the relationship between biodiversity and ecosystem functioning is related to the trophic state of a lake. In addition, copepod abundance is likely to reach a high level at two conditions: intermediate level of evenness and low biomass proportion of Cyanophyta.

When analyzing the relationship between biodiversity and ecosystem functioning, ecologists found that the influence of plant species richness and evenness may be different, especially in aquatic ecosystems [11,12,35]. Ptacnik et al. [11] obtained a positive correlation between phytoplankton species richness and resource use efficiency, while Filstrup et al. [12] found that phytoplankton evenness had a negative influence on resource use efficiency. In this study, we discovered that phytoplankton evenness had a negative correlation with copepod abundance while no effect of species richness was apparent. Evenness generally responds more rapidly to the fluctuation of environmental factors than species richness because many species become rare before becoming locally extinct [35,36]. Rare species may have little impact on ecosystem functioning, and therefore species richness would often overestimate the importance of rare species [12]. The results in this study showed that copepod abundance was more sensitive to the variation of phytoplankton evenness than species richness, which was consistent with previous studies $[12,35,36]$. On the basis of these results, a distinction should be made between species richness and evenness when analyzing the relationship between phytoplankton diversity and ecosystem functioning.

It is believed that the predator-prey interaction between phytoplankton and zooplankton is a determinable mechanism in aquatic ecosystems $[17,18]$. The increase of phytoplankton biomass will promote the growth of zooplankton, and in turn leading to greater phytoplankton consumption [37,38]. The relationships between the two variables are related to the trophic condition of a lake: in oligotrophic lakes, zooplankton is dominated by small-sized individuals and phytoplankton biomass will benefit the growth of zooplankton; in eutrophic lakes, phytoplankton is generally dominated by cyanobacteria, which is grazing-resistant species and phytoplankton biomass will limiting the growth of zooplankton; in mesotrophic lakes, zooplankton is often dominated by efficient grazer Daphnia and copepods, the relationship between phytoplankton and zooplankton biomasses is complex [19,20]. In this study, most of the sites in Lake Nansihu are in mesotrophic or light-eutrophic state (Table 1), and we found no apparent relationship between phytoplankton biomass and copepods. Long-term observations of predator-prey systems have sometimes showed complex or even chaotic plankton abundance dynamics [37,38]. Therefore, a coupled oscillation between the biomasses of phytoplankton and zooplankton may be a good relationship.

In lake ecosystems, zooplankton is generally influenced by both bottom-up and top-down effects [39]. Fish species have great influence on plankton and are usually used to control algae blooms through trophic cascading [39]. In Lake Nansihu, Carassius auratus was the main fish species, with a biomass proportion of $69.15 \%$ [40], and the biomass proportion of Cyprinidae was higher than $90 \%$ of total fish biomass. Specziár et al. [41] observed that copepod biomass accounted for $4.4 \%$ of the total gut content of Cyprinidae. Thus in Lake Nansihu, copepods were mainly influenced by bottom-up effects and the effect of fish species was relatively weak.

Both biodiversity and ecosystem functioning are multidimensional and with a wide variety of definitions, therefore, the relationship between them is a complex and long-term topic [3,42]. 
However, until now, little has been known about how phytoplankton diversity affects ecosystem functioning. Given the importance of aquatic ecosystems and the special ecophysiological traits of plankton community $[8,43,44]$, further investigations in this field will be critical for improving our understanding of these phenomena.

\section{Conclusions}

In this study, the relationship between phytoplankton (evenness, species richness and biomass) and copepod abundance was analyzed at Lake Nansihu, China. The main findings of the present research can be summarized in the following conclusions:

(1) A total of 138 phytoplankton species belonging to 78 genera and eight phyla were identified, including 60 Chlorophyta species, 33 Bacillariophyta species, and 20 Cyanophyta species, phytoplankton biomass varied from $0.44 \mathrm{mg} / \mathrm{L}$ to $5.46 \mathrm{mg} / \mathrm{L}$ and Chlorophyta was the dominant community;

(2) There were 12 copepod species in the lake and their mean abundance ranged between $38.6 \mathrm{ind} . / \mathrm{L}$ and 95.1 ind./L in different seasons;

(3) Copepod abundance was significantly decreased with increasing phytoplankton evenness throughout the year, and both phytoplankton species richness and biomass had no significant correlation with the abundance of copepods;

(4) The influence of phytoplankton species richness and evenness was different and most copepods species were more sensitive to the variation of phytoplankton evenness than species richness.

The results of this study provide important new insights into the relationship between phytoplankton diversity and ecosystem functioning.

Acknowledgments: We would thank Jian Zhang and Mingsheng Miao for their helpful works in field investigations. We extend our thanks to Tornillo Scientific and Mireia Tomas for the assistance in language editing. This study was financially supported by the National Special Water Programs (No. 2009ZX07210-009, No. 2015ZX07203-011, No. 2015ZX07204-007), Department of Environmental Protection of Shan Dong Province (SDHBPJ-ZB-08, Investigating and evaluating ecological security of Lake Nansihu).

Author Contributions: Huayong Zhang and Wang Tian were responsible for the research design. Wang Tian, Lei Zhao, Xiang Xu and Hai Huang analyzed the data and prepared the figures. Wang Tian drafted the main text. All authors were participated in discussions and editing.

Conflicts of Interest: The authors declare no conflict of interest.

\section{References}

1. Dudgeon, D.; Arthington, A.H.; Gessner, M.O.; Kawabata, Z.I.; Knowler, D.J.; Lévêque, C.; Naiman, R.J.; Prieur-Richard, A.H.; Soto, D.; Stiassny, M.L.J.; et al. Freshwater biodiversity: Importance, threats, status and conservation challenges. Biol. Rev. 2006, 81, 163-182. [CrossRef] [PubMed]

2. Chalar, G. The use of phytoplankton patterns of diversity for algal bloom management. Limnol.-Ecol. Manag. Inland Waters 2009, 39, 200-208. [CrossRef]

3. Cardinale, B.J.; Duffy, J.E.; Gonzalez, A.; Hooper, D.U.; Perrings, C.; Venail, P.; Narwani, A.; Mace, G.M.; Tilman, D.; Wardle, D.A.; et al. Biodiversity loss and its impact on humanity. Nature 2012, 486, 59-67. [CrossRef] [PubMed]

4. Hulot, F.D.; Lacroix, G.; Lescher-Moutoué, F.; Loreau, M. Functional diversity governs ecosystem response to nutrient enrichment. Nature 2000, 405, 340-344. [CrossRef] [PubMed]

5. Weyhenmeyer, G.A.; Peter, H.; Willen, E. Shifts in phytoplankton species richness and biomass along a latitudinal gradient-consequences for relationships between biodiversity and ecosystem functioning. Freshwater Biol. 2013, 58, 612-623. [CrossRef]

6. Sun, C.C.; Wang, Y.S.; Wu, M.L.; Dong, J.D.; Wang, Y.T.; Sun, F.L.; Zhang, Y.Y. Seasonal variation of water quality and phytoplankton response patterns in Daya Bay, China. Int. J. Environ. Res. Public Health 2011, 8 , 2951-2966. [CrossRef] [PubMed] 
7. Mulvenna, V.; Dale, K.; Priestly, B.; Mueller, U.; Humpage, A.; Shaw, G.; Allinson, G.; Falconer, I. Health risk assessment for cyanobacterial toxins in seafood. Int. J. Environ. Res. Public Health 2012, 9, 807-820. [CrossRef] [PubMed]

8. Giller, P.S.; Hillebrand, H.; Berninger, U.G.; Gessner, M.O.; Hawkins, S.; Inchausti, P.; Inglis, C.; Leslie, H.; Malmqvist, B.; Monaghan, M.T.; et al. Biodiversity effects on ecosystem functioning: Emerging issues and their experimental test in aquatic environments. Oikos 2004, 104, 423-436. [CrossRef]

9. Sommer, U.; Gliwicz, Z.M.; Lampert, W.; Duncan, A. The PEG-model of seasonal succession of planktonic events in fresh waters. Arch. Hydrobiol. 1986, 106, 433-471.

10. Shurin, J.B.; Arnott, S.E.; Hillebrand, H.; Longmuir, A.; Pinel-Alloul, B.; Winder, M.; Yan, N.D. Diversity-stability relationship varies with latitude in zooplankton. Ecol. Lett. 2007, 10, 127-134. [CrossRef] [PubMed]

11. Ptacnik, R.; Solimini, A.G.; Andersen, T.; Tamminen, T.; Brettum, P.; Lepistö, L.; Willén, E.; Rekolainen, S. Diversity predicts stability and resource use efficiency in natural phytoplankton communities. Proc. Natl. Acad. Sci. USA 2008, 105, 5134-5138. [CrossRef] [PubMed]

12. Filstrup, C.T.; Hillebrand, H.; Heathcote, A.J.; Harpole, W.S.; Downing, J.A. Cyanobacteria dominance influences resource use efficiency and community turnover in phytoplankton and zooplankton communities. Ecol. Lett. 2014, 17, 464-474. [CrossRef] [PubMed]

13. Duffy, J.E.; Cardinale, B.J.; France, K.E.; McIntyre, P.B.; Thébault, E.; Loreau, M. The functional role of biodiversity in ecosystems: Incorporating trophic complexity. Ecol. Lett. 2007, 10, 522-538. [CrossRef] [PubMed]

14. Striebel, M.; Singer, G.; Stibor, H.; Andersen, T. “Trophic overyielding”: Phytoplankton diversity promotes zooplankton productivity. Ecology 2012, 93, 2719-2727. [CrossRef] [PubMed]

15. Duffy, J.E. Biodiversity and ecosystem function: The consumer connection. Oikos 2002, 99, $201-219$. [CrossRef]

16. Keesing, F.; Holt, R.D.; Ostfeld, R.S. Effects of species diversity on disease risk. Ecol. Lett. 2006, 9, 485-498. [CrossRef] [PubMed]

17. Grover, J.P. Stoichiometry, herbivory and competition for nutrients: Simple models based on planktonic ecosystems. J. Theor. Biol. 2002, 214, 599-618. [CrossRef] [PubMed]

18. Prowe, A.E.F.; Pahlow, M.; Dutkiewicz, S.; Follows, M.; Oschlies, A. Top-down control of marine phytoplankton diversity in a global ecosystem model. Prog. Oceanogr. 2012, 101, 1-13. [CrossRef]

19. Elser, J.J.; Goldman, C.R. Zooplankton effects on phytoplankton in lakes of contrasting trophic status. Limnol. Oceanogr. 1991, 36, 64-90. [CrossRef]

20. Carney, H.J.; Elser, J.J. Strength of zooplankton-phytoplankton coupling in relation to lake trophic state. In Large Lakes; Tilzer, M.M., Serruya, C., Eds.; Springer Berlin Heidelberg: Berlin, Germany, 1990; pp. 616-631.

21. Christensen, S.C.; Arvin, E.; Nissen, E.; Albrechtsen, H.J. Asellus aquaticus as a potential carrier of Escherichia coli and other coliform bacteria into drinking water distribution systems. Int. J. Environ. Res. Public Health 2013, 10, 845-855. [CrossRef] [PubMed]

22. Apaydın Yağc1, M. Seasonal variations in zooplankton species of Lake Gölhisar, a shallow lake in Burdur, Turkey. Pak. J. Zool. 2014, 46, 927-932.

23. Maqbool, A.; Sulehria, A.Q.K.; Ejaz, M.; Hussain, A. Study on pelagic copepods from Pipnakha Village, District Gujranwala, Pakistan. Pak. J. Zool. 2015, 47, 1347-1353.

24. Huntley, M.E.; Lopez, M.D.G. Temperature-dependent production of marine copepods: A global synthesis. Am. Nat. 1992, 140, 201-242. [CrossRef] [PubMed]

25. Turner, J.T. The importance of small planktonic copepods and their roles in pelagic marine food webs. Zool. Stud. 2004, 43, 255-266.

26. Shu, F.Y.; Liu, Y.P.; Zhao, Y.; Wu, Y.P.; Li, A.H. Spatio-temporal distribution of TN and TP in water and evaluation of eutrophic state of Lake Nansi. Environ. Sci. 2012, 33, 3748-3752. (In Chinese)

27. Zhang, Z.L.; Xin, L.J.; Liang, C.L. The analysis of hydrological characteristics and processes of ecosystem in Lake Nansi during the past 50 years. Geogr. Res. 2007, 26, 957-966. (In Chinese)

28. Gong, J.X.; Duan, D.X.; Wang, Z.Z.; Du, X.H.; Zhang, J.L.; Liu, H.C.; Chen, J.P.; Sun, D. Research and analysis on the plankton of Nansi Lake. J. Yangtze Univ. (Nat. Sci. Ed.) 2010, 7, 39-42. (In Chinese)

29. Wu, Z.H.; Zhang, K.; Jin, L.R.; Yang, L.K.; Zhang, J. Analysis of spatial distribution of water quality and assessment of water quality improvement in Nansi Lake. Water Resour. Prot. 2012, 28, 1-7. (In Chinese) 
30. Tang, J.; Xiang, J.G.; Gu, P.H.; Xie, M.; Shu, F.Y.; Xie, S.G. Community structure of zooplankton and assessment of water quality in Weishan Lake. Chin. J. Fish. 2014, 27, 32-37. (In Chinese)

31. Feng, Y.W.; Hou, K.; Pei, H.Y.; Hu, W.R.; Ren, Y.; Wei, J.L. Desmid community characteristics and its relationship with environmental variables in Nansi Lake and Dongping Lake. Chin. J. Ecol. 2015, 34, 1738-1746. (In Chinese)

32. Arhonditsis, G.B.; Winder, M.; Brett, M.T.; Schindler, D.E. Patterns and mechanisms of phytoplankton variability in Lake Washington (USA). Water Res. 2004, 38, 4013-4027. [CrossRef] [PubMed]

33. Sun, J.; Liu, D.Y.; Qian, S.B. Study on phytoplankton biomass I: Phytoplankton measurement biomass from cell volume or plasma volume. Acta Oceanol. Sin. 1999, 21, 75-85. (In Chinese)

34. Pielou, E.C. The measurement of diversity in different types of biological collections. J. Theor. Biol. 1966, 13, 131-144. [CrossRef]

35. Hillebrand, H.; Bennett, D.M.; Cadotte, M.W. Consequences of dominance: A review of evenness effects on local and regional ecosystem processes. Ecology 2008, 89, 1510-1520. [CrossRef] [PubMed]

36. Chapin, F.S.; Zavaleta, E.S.; Eviner, V.T.; Naylor, R.L.; Vitousek, P.M.; Reynolds, H.L.; Hooper, D.U.; Lavorel, S.; Sala, O.E.; Hobbie, S.E.; et al. Consequences of changing biodiversity. Nature 2000, 405, 234-242. [CrossRef] [PubMed]

37. Vandermeer, J. Coupled oscillations in food webs: Balancing competition and mutualism in simple ecological models. Am. Nat. 2004, 163, 857-867. [CrossRef] [PubMed]

38. Benincà, E.; Jöhnk, K.D.; Heerkloss, R.; Huisman, J. Coupled predator-prey oscillations in a chaotic food web. Ecol. Lett. 2009, 12, 1367-1378. [CrossRef] [PubMed]

39. Carpenter, S.R.; Kitchell, J.F.; Hodgson, J.R. Cascading trophic interactions and lake productivity. BioScience 1985, 35, 634-639. [CrossRef]

40. Li, F.; Zeng, G.; Song, J.; Dong, L.; Xi, X. The responses of fish community of Nansi lake to the east route of the south-to-north water transfer project. Henan Sci. 2008, 26, 467-471. (In Chinese)

41. Specziár, A.; Tölg, L.; Bíró, P. Feeding strategy and growth of cyprinids in the littoral zone of Lake Balaton. J. Fish. Biol. 1997, 51, 1109-1124.

42. Donohue, I.; Petchey, O.L.; Montoya, J.M.; Jackson, A.L.; McNally, L.; Viana, M.; Healy, K.; Lurgi, M.; O'Connor, N.E.; Emmerson, M.C. On the dimensionality of ecological stability. Ecol. Lett. 2013, 16, 421-429. [CrossRef] [PubMed]

43. Litchman, E.; Klausmeier, C.A. Trait-based community ecology of phytoplankton. Annu. Rev. Ecol. Evol. Syst. 2008, 39, 615-639. [CrossRef]

44. Wang, Y.; Jiang, H.; Jin, J.; Zhang, X.; Lu, X.; Wang, Y. Spatial-temporal variations of chlorophyll-A in the adjacent sea area of the Yangtze River estuary influenced by Yangtze River discharge. Int. J. Environ. Res. Public Health 2015, 12, 5420-5438. [CrossRef] [PubMed]

(C) 2016 by the authors; licensee MDPI, Basel, Switzerland. This article is an open access article distributed under the terms and conditions of the Creative Commons Attribution (CC-BY) license (http:/ / creativecommons.org/licenses/by/4.0/). 